\title{
The Correlation Between Principal and Motivation to The Teachers' Satisfaction
}

\author{
Amiruddin \\ Department of Educational Management \\ State University of Medan, Indonesia \\ amirhsb84@gmail.com
}

\author{
H. Syaiful Sagala \\ Lecturer of State University of \\ Medan, Indonesia \\ saiful_sagala@yahoo.co.id
}

\begin{abstract}
The teacher' satisfaction is shown by the attitude in working or in teaching. If the teacher feels satisfaction with the situation that can influence them, so they will work or teach well. The purposes of this research was to find out the correlation between principal supervision and teachers' satisfaction; correlation between motivation and teachers' satisfaction; and principal as supervisor and motivation together with teachers' satisfaction. This study is correlational. The population is 311 teachers. The sample is 61 teachers. The result of this research were there were significant correlation between principal supervision and teachers' satisfaction, $t_{\text {count }}=4,979>t_{\text {table }}=1,671$; there were significant correlation between motivation and teachers' satisfaction, $t_{\text {count }}=9,357>t_{\text {table }}=1,671$; there is significant correlation between principal supervision and teachers' motivation together with teachers' satisfaction, $F_{\text {coun }} t=5,23>F_{\text {table }}=3,15$. Based on the data and the result of this research, it could be concluded that principal supervision had contribution in increasing teachers' satisfaction in doing their professionalism as educators. This research was also shown that motivation in the teachers themselves could increase teachers' satisfaction.
\end{abstract}

Keywords: work satisfaction, supervision, motivation

\section{INTRODUCTION}

Job satisfaction is a circumstance of teacher emotional that occur or not occur of interaction between the limitation of teacher's services with the level of the remuneration value of both financial and nonfinancial services. Job satisfaction is the level where someone feels both positive or negatives about various facets of the work, workplace, and relationships with co-workers.

The teacher who is satisfied with his/her work will have a positive attitude with the job so that will push ahead as well as possible to do the job, on the contrary there is absenteeism, poor work, passionate teaching less, thievery, low achievement, movement/ teacher displacement is the result of teacher's dissatisfaction over the organizational treatment to him/her.

The teachers will feel satisfy to work if they have the perception of the difference between the desired conditions and deficiencies can be met according to actual conditions (reality), teachers will satisfy if the benefits that their received have been issued balance with the energy and individuals cost, and teachers will satisfy if there are spark factors job satisfaction (satisfier) is more dominant than the trigger factors of dissatisfaction (dissatisfied).

Teachers' job satisfaction can be implemented in several ways such as the organization can create an organizational climate in favor of teachers' prosperity, extroverted and emphasize on achievement, can be enhanced satisfaction using motivation factors also, especially the teachers' achievement motivation, because the task of the teacher concerned with the students' success which is an educational success. Teacher' work is a collection of tasks to achieve educational purpose. Satisfaction in performing tasks is an important aspect to a person's performance or productivity, this is because most of the teachers' time is used to work.
Teachers are required to work by providing the best service to the school users such as students, parents, and the community. One of the factors can support to the teacher to do the best in services is job satisfaction. This means that if teachers satisfy to organizational behavior (school) then they will work vigorously and.

The data that had been found from the headmaster and school treasurer of Public Junior High School at sub-district Percut Sei Tuan where teachers get teacher incentives / teacher allowance from North Sumatra Governor's policy and SBY' incentives to improve teacher' performance in teaching and learning process by giving incentive can be seen in the following data table:

\begin{tabular}{|c|c|c|c|}
\hline $\begin{array}{c}\text { Incentive/ } \\
\text { Allowance }\end{array}$ & $\begin{array}{c}\text { Rp (6 bln } \\
\text { \& 3 bln) }\end{array}$ & $\begin{array}{c}\text { PPH 10\% } \\
\mathbf{8 1 5 \%}\end{array}$ & $\begin{array}{c}\text { Amount (Rp) } \\
\text { Be accepted }\end{array}$ \\
\hline $\begin{array}{c}\text { Governor of } \\
\text { North }\end{array}$ & $60.000,00$ & 36.000 & $360.000,00$ \\
Sumatera & & & \\
\hline $\begin{array}{c}\text { Susilo } \\
\text { Bambang } \\
\text { Yudhoyono }\end{array}$ & $250.000,00$ & 112.500 & $637.000,00$ \\
\hline \multicolumn{2}{|l|}{} & & \\
\hline
\end{tabular}
sub-district Percut Sei Tuan Deli Serdang Regency Year 2011 Data.

With details of Rp 60.000,00 every month with income tax deduction $10 \%$. This money had been given in every six months so that the total to be Rp $360.000,00$. Likewise, with the results of current government policies that are named Susilo Bambang Yudhoyono incentives in the amount of Rp. $250.000,00$ every month with income tax deduction $15 \%$. This money had been given for every three months, so that the total to be Rp. 637.500,00. This one of government' policies to improve the teacher' work in generating job satisfaction as an educator in-depth educational world. But in fact or in interview result show that by giving the incentive to the teacher who taught at Public Junior High School at sub-district Percut Sei 
Tuan did not seriously shown the teacher job satisfaction result in teaching-learning process or in school organization. This is one of existing phenomena at Public Junior High School at sub-district Percut Sei Tuan that suitable with the interview result between the writer and some of teachers that found at Public Junior High School at sub-district Percut Sei Tuan from job dissatisfaction among them. Indicated from there are symptoms of absenteeism in the school environment, spirit at work low, teacher' discipline still low and dissatisfaction to the work place condition and the state of students is a lot of annoying.

Teacher complain not only incentive factor of SBY President and Governor that the incentive was still low for them and less to meet the increasingly growing economic needs, but also other factors like saturate work, the atmosphere of work environment that is not conducive like a friend who is not mutually support /motivate, less wise leaders and students whose behavior is irritating. On the other hand, there are those who dropped their spirits in teaching, feeling bored, bored with them.

In addition to the above problems the reality of the results of observation and interview way in July 2011 that existed in the Public Junior High School sub-district Percut Sei Tuan, district Deli Serdang based on the results of interviews with the vice headmaster I of the curriculum section of the school that there are several things that can effect of teachers' job satisfaction, such as: lack of teachers' competence in teaching, teacher' discipline still low, it can be proved by the total of 61 teachers who taught there collect the activities of learning devices on time totaling $15 \%$ people only, this data shows that the quality of teachers, work spirit is still low, there are still many teachers who teaches there still use the traditional way and not all of them refer to the demands of curriculum and affective learning activities, innovative and creative, and fun that at the present time is known as (PAIKEM), not all teachers prepare teaching planning (RPP) in teaching so that the aims of learning to be achieved are also not clear yet, finally have an impact on the low achievement of students. Dissatisfaction with this work, resulting in less teachers' enthusiasm in performing their duties as educators. Thus, the teacher assumes that teaching is only a routine activity to deliver a number of school subject matter to students, after it's done.

Robbins and Mary Coulter [1] said that job satisfaction is "the relationship of managers to job satisfaction is centered on the impact on employee performance". Furthermore, Robbins writes that researchers have captured the association, thus finding many studies that designed to assess the impact of satisfaction on employee productivity, absence, and resignation.

Meanwhile, according to Gibson, Ivancevich and Donnelly [2] that job satisfaction starts from various aspects of work, such as wages, promotion opportunities, supervision, coworkers, as well as work environment factors, policies and procedures, group membership, working conditions and benefits.

From the above opinion of Robbins and Gibson can be concluded that it is very important that the teacher's job satisfaction is noticed and realized by people associated with educational institutions or schools, especially the principal as the leader of the school, because, if the teacher job satisfaction is high or satisfactory, then the teacher will work with passion and more active and effective, as well as willingly planned or in other words the level of teacher performance will increase and schools will have a high effectiveness in the learning process also.

According to Kumar [3] teacher job satisfaction is a complex symptom that has various related factors, namely personal, social, cultural and economic. Teacher's Job satisfaction is the result of various attitudes of a teacher to his work and to factors related to his work also. While Suwar [4] expresses teacher's job satisfaction is the teacher's sense of fun or not about work based on the expectation of the teacher in rewarding that is given by the school. Teacher job satisfaction is shown by his attitude in work or teaching. If the teacher is satisfied with the circumstances that affect him, then he will work or teach well. Lester's continuation in Hughes [5] teacher's job satisfaction is the extent to which a teacher's acceptance and values to aspects of a job such as evaluation, peer relations, responsibility, and recognition.

Therefore, paying attention to job satisfaction is important to improve employee performance and productivity. According to Locke as quoted by Sopiah [6], job satisfaction is pleasurable or positive emotional state resulting from the appraisal of one's job or job experience.". Thus job satisfaction has the quality both positive and also negative. These positive and negative emotional expressions are revealed after the goal is reached. Each individual will compare what is earned with what is expected. Therefore, satisfaction according to Winardi [7] is an end condition (an end state) that arise due to the achievement of certain goals.

From the above explanation, to give attention to teacher job satisfaction is very important, because in the end it will lead to seriousness in performing the duties as educators, do not feel forced, be responsible in achieving the desired school goals. Thus, the teacher's job satisfaction will lead to increased productivity and spur the achievement of an effective school.

This will be a challenge for ensuring the quality of principal's education as well as the closest and closest supervisors to teachers, have to have a sensitivity in understanding all of this. But the problem is how many principals understand the teacher's job satisfaction? Even the leadership of the principal often becomes the trigger of teacher's job satisfaction becomes low this due to the lack of role of the principal to supervise the teacher. Or perhaps the principal's decision / policy has indirectly caused a teacher to feel dissatisfied at work. Teacher performance can be low because of dissatisfaction with the principal only. Dissatisfaction on work can be due to teachers assuming that the principal's attention is very low or in other words rarely the principal's role in supervising the teacher in the learning process, this will result in low teacher job satisfaction and do not produce satisfactory productivity in school education. teachers do not feel like being the closest part of the principal because the principal does not show empathy, understanding the teachers well, and do not get involved in the problems faced by teachers.

The communication between teachers and principals must be optimized, we often mistakenly perceive or even suspect each other because of ignorance of each side. Therefore, it is very wise if the principal as a role model of school residents 
want to give a good example as well as want to build communication with school residents with full kinship. During this time the headmaster, the new majority just complained about his men, while they were at their disposal and quibble in the duty of outside service without the knowledge of his subordinates.

Supervision in the classroom by the principal is a communication bridge between the teacher and the leader. Therefore, it should be the implementation frequency of this supervision always to be improved or even maximized. Through this step believe that in communication between teachers and principals will be added harmoniously. Both parties understand each other's educational needs and will certainly produce mutual understanding. This is very important in order to improve teacher work satisfaction and work productivity so that schools can achieve optimal results as well.

Teachers who are motivated to work will generate job satisfaction, because the teacher's needs accomplished encourage teachers to improve performance. Principal supervisory activities are psychologically influential on teacher's work satisfaction, if teachers are satisfied with the principal's supervision and high motivation achievement so he will work voluntarily which can ultimately make teacher work productivity increase. But if the teacher is not satisfied with the implementation of the principal's supervision and low motivation achievement, the teacher will be in the lessmotivated work causes the teacher's productivity to decrease.

There are teachers who have high motivation achievement because they get promotion, get benefits, but there are also teachers whose motivation is low because he does not get promotion. Achievement motivation related to welfare, work environment, career development opportunities, and additional services to teachers.

From the description of the teacher work satisfaction can be influenced by achievement motivation factor. This is based on the assumption that working without motivation will get bored quickly, because there is no driving force to keep work morale. Motivation is a commodity that is needed by everyone, including teachers. Motivation is needed to live life, lead a group of people and achieve organizational goals. Achievement motivation is an encouragement that grows and develops from within the teacher to do the best job possible so that the goal will be achieved. Achievement motivation can occur if the teacher has pride in success. Though the teaching task is a proud and challenging task, so teachers should have achievement motivation.

Based on the foregoing description, the question arises whether there is a relationship of principal supervision and achievement motivation with teacher work satisfaction. This is given that teachers are the spearhead of success in improving the quality of education. To the authors conduct research on teacher job satisfaction and changes that can make a meaningful contribution for teachers.

\section{METHODS}

This research is a correlational descriptive research, where the data obtained are revealed based on facts in the field. Then, the data are analyzed by descriptive statistical analysis method and correlational analysis. The total number of teachers 311 people spread 6 State Junior High Schools in
Sub-District Percut Sei Tuan Deli Serdang District. The sample of this research is some teachers from State Junior High School in Sub-District Percut Sei Tuan Deli Serdang District. Sampling is done with proportional stratified random sampling. With a population of 311 people and produce a sample of 61 people, that is $61 / 311$ X $100 \%=19,61 \%$.

\section{Data Collection Techniques and Research Instruments}

1. Research Instrument

The data collection tool in this research is using questionnaire.

2. Testing of Instruments and Research Instruments

a. Test of Grain Validity

To find out the instrument determination is validity test by using product moment correlation formula. The criterion used to test the validity of the grains have a correlation coefficient $r_{\text {count }}>r_{\text {table, at a }}$ significant level $\alpha=0,05$. It means the item is valid if $r_{\text {count }}>r_{\text {table, }}$ otherwise if $r_{\text {count }} \leq r_{\text {table }}$ declared invalid. The invalid item does not used.

b. Reliability of instrument Test

Questionnaire that used must be valid and reliable, therefore reliability questionnaire will be analyzed by Cronbach Alpha technique (1984).

To obtain valid items from each indicator is done by finding correlations between the instrument items of each indicator. According to Husaini and Akbar [8] for $r$ less than 0.80 declared void (not reliable)

\section{Data Analysis and Hypothesis Test Techniques}

The data obtained were analysis by using statistical techniques that the test requirements of data analysis and hypothesis testy use computer program Excel and SPSS.

1) Data Description

The data obtained are first searched for the average count and standard deviation to be studied. To find the average count used the formula:

$\mathrm{Me}=\sum \mathrm{fx} / \sum \mathrm{f}$ Sudjana [9].

To find of deviation standard was used the formula below: Sudjana [9].

$$
S D=\frac{n \cdot \sum f x^{2}-\left(\sum f x\right)^{2}}{n(n-1)}
$$

2) Category of data tendency of each variable

Data of each research variable will be described by using descriptive statistics, where to identify when the variable as reference used the average value of the ideal score (Mi) and ideal deviation standard (SDi) of all research objects. Arikunto [10].

3) Analysis Requirements Test

a. Normality Test

To know the normality of data, it is used the data normality test by using the Lilliefors test and the error estimation test of $\mathrm{Y}$ over $\mathrm{X}$ is intended to determine whether the regression error of $\mathrm{Y}$ over $\mathrm{X}$ is normally distributed or not. This testing criterion is if $F\left(Z_{1}\right)-S$ $\left(\mathrm{Z}_{1}\right)$ with largest balanced $\mathrm{L}_{0}<\mathrm{L}_{0 \text { table }}$ at a significant level 0,05 . If the requirements are met, then the sample comes from a normally distributed population. 
b. Homogeneity Test

Homogeneity tests are needed to see if the population group data obtained have homogeneous variance or not. One of the techniques to test homogeneity according to Usman and Akbar [8] is Bartlett Test. The homogeneity of data tested is $\mathrm{Y}$ over $\mathrm{X} 1$ and $\mathrm{Y}$ over $\mathrm{X}_{2}$. The test criteria are used if $X_{\text {count }}^{2}<X_{\text {table, }}^{2}$ then the homogeneous variant, at a significant level $\alpha=0,05 . \mathrm{X}_{\text {count }}^{2}$ was counted by using the formula below:

$$
X^{2}=(\operatorname{In} 10)\left[\mathrm{B}-\sum d b \log \mathrm{S}_{\mathrm{i}}^{2}\right]
$$

where:

$$
\frac{B=\left(\sum d b\right) \log S^{2}}{S^{2}=\sum d b S_{i}{ }^{2}}
$$

$$
\sum d b
$$

c. Data Linearity Test

Test linearity of data is done to ensure whether the regression obtained is meaningful when used to make conclusions about the relationship between the variables that analyzed with the level of trust $95 \%$. Linearity test and regression coefficient was done by using coefficient as follows:

$$
\begin{gathered}
a=\frac{\begin{array}{c}
\mathrm{Y}=\mathrm{a}+\mathrm{b} \mathrm{Xi} \\
\left.\sum Y\right)\left(\sum X^{2}\right)-\left(\sum X\right)\left(\sum X Y\right)
\end{array}}{n\left(\sum X^{2}\right)-\left(\sum X\right)^{2}} \\
b=\frac{n\left(\sum Y\right)\left(\sum X^{2}\right)-\left(\sum X\right)\left(\sum X Y\right)}{n\left(\sum X^{2}\right)-\left(\sum X\right)^{2}}
\end{gathered}
$$

\section{RESULT AND DISCUSSION}

1. The Correlation between Principal Supervision and Teacher's Job Satisfaction

From the descriptive table of principal supervision variables shows that the lowest score is 66 and the highest is. Average 81,15, Standard Deviation 9,21, median 81,46, and modus 82,10. The correlation coefficient obtained for principal supervision variable with teacher work satisfaction is 0,544 with the determination coefficient 0,296 . It means 29,6 $\%$ teacher's job satisfaction is determined by the principal's supervision. This means that the increase in the supervision of the principal will be followed by an increase in teacher work satisfaction. This correlation is expressed significantly marked by the sig value at the output SPSS Table 4: 9 of value 0,000 and is under $\alpha$ is 0,05 .

Gibson, Ivancevich and Donnelly [2] said that job satisfaction starts from various aspects of work, such as wages, promotional opportunities, supervision, co-workers, as well as work environment factors, policies and procedures, group membership, working conditions and benefits. So with a decent wage, then the teacher will get satisfaction in work, in addition to promotional opportunities is also one that can get job satisfaction for teachers. Supervision in this case the principal's supervision relates to the job satisfaction of teachers, because of the principal's supervision accordingly the teacher will get the attention of the leader who in the end can improve the teachers' quality in implementing the teaching-learning process.

This finding is supported by Sunardi [11] Relationship Principal's Supervision and Teachers' Work Motivation With Teachers' Job Satisfaction State Senior High School Seaman Samarinda. The results of the study found that there is a positive correlation between principal's supervision $\left(\mathrm{X}_{1}\right)$ with job satisfaction (Y) with coefficients $r_{\mathrm{y} 1}=0,52$.

\section{The Correlation between Achievement Motivation with} Teacher's Work Satisfaction

From the descriptive table of achievement motivation variable is known that the lowest score is 63 and the highest is 94. On average 77.98, standard deviation of 8.55 , median 78.10, and mode 76.10. The correlation coefficient obtained for achievement motivation variable with teacher work satisfaction is 0,768 with coefficient of determination equal to 0,589 . This means that $58.9 \%$ of teacher job satisfaction is determined by achievement motivation. This correlation is positive; it means that the increase in achievement motivation will be followed by an increase in teacher work satisfaction. This correlation is expressed significantly marked by the value of sig in Table 4.13 SPSS output value 0.000 and is below $\alpha$ namely 0,05 .

Based on the correlation coefficient classification expressed by Surakhmad 1985 (Somantri dan Muhidin, 2006: 214) accordingly the correlation coefficient between achievement motivation and teacher work satisfaction in enough category. This is in line with the research that was conducted by Yunus [12] Correlational Studies Between Organizational climate And Outstanding Motivation With Master Work Satisfaction. The results of the study found that there is a positive relationship between achievement motivation $\left(\mathrm{X}_{2}\right)$ with job satisfaction $(\mathrm{Y})$ with coefficients $\mathrm{r}_{\mathrm{y} 2}$ $=0,934$ and regression equations $\mathrm{Y}=0,880+0,967 \mathrm{X}_{2}$.

Achievement motivation is an encouragement that grows and develops from within the teacher to do the best job possible so that the goal will be achieved. Achievement motivation can occur if the teacher has pride in success. Though the teaching task is a proud and challenging task, so teachers should have achievement motivation.

3. The Correlation between Principal's Supervision and Outstanding Motivation with Teacher's Job Satisfaction

Principal's supervision $\left(\mathrm{X}_{1}\right)$ and outstanding motivation $\left(\mathrm{X}_{2}\right)$ together resulting a correlation coefficient in the amount of 0,391 . The determination coefficient obtained is 0,153 . It means $15,3 \%$ teacher job satisfaction can be explained by the principal's supervision and achievement motivation. Based on the classification of correlation coefficients that expressed by Surakhmad 1985 (Somantri dan Muhidin, 2006:214) accordingly the correlation coefficient between principal's supervision and achievement motivation together with teacher job satisfaction is enough categorized because it is in interval of 0,70 till 0,90 . 
Furthermore, the regression equation formed between research variables is $\mathrm{Y}=1,424+0,273 \mathrm{X}_{1}+0,689 \mathrm{X}_{2}$. This value shows that the coefficient of achievement motivation $\left(\mathrm{X}_{2}\right)$ greater than the principal's supervision coefficient $\left(\mathrm{X}_{1}\right)$.

The results of this study indicate that one of the ways to improve teacher's work satisfaction is improving principal's supervision and improve work motivation. Sunardi research results [11] shows that there is a positive relationship between principal's supervision and work motivation with job satisfaction is by $r=0,52$ coefficient. The results of this study imply that to improve teacher's work satisfaction by improving the implementation of Principal's supervision and improving work motivation.

According to Gilmer in Sopiah [6] that aspects that can affect job satisfaction that are: promotion, job security, salary, company and management, working conditions, supervision, intrinsic factors of work, social aspects of work, communication and coworkers.

\section{CONCLUSION}

Based on the above data and analysis results presented, the following conclusions can be drawn:

1. There is a significant and meaningful relationship between principal's supervision and teacher's job satisfaction. The correlation coefficient that obtained is 0,544 . From the calculation show that $t_{\text {count }}=4,979$, while the $t_{\text {tabel }}$ value with $\mathrm{db} .=59$ obtained about 1,671 . Therefore, $t_{\text {count }}>t_{\text {table }}$ $(4,979>1,671)$, it can be concluded that between the principal's supervision has a positive and significant relationship with teacher's job satisfaction. This indicates how important the principal's supervision is in improving job satisfaction. Based on the research findings can be concluded that the research hypothesis that stated there is a relationship between the principal's supervision with teacher's work satisfaction can be accepted.

2. There is a significant and meaningful relationship between achievement motivation and teacher's work satisfaction. The correlation coefficient that obtained is 0,768 . The calculation result that $t_{\text {count }}=9,357$, while the $t_{\text {table }}$ value with $\mathrm{db} .=59$ obtained about 1,671 . Therefore, $t_{\text {count }}>t_{\text {table }}$ $(9,357>1,671)$, it can be concluded that achievement motivation has a positive and significant relationship with teacher's job satisfaction. This condition implies that achievement motivation coverage is one of the things in improving teacher's work satisfaction. Based on the findings of this study can be concluded that the hypothesis of research that stated there is a relationship between achievement motivation with teacher's work satisfaction can be accepted.
3. There is a significant relationship between principal's supervision and achievement motivation together with teacher's job satisfaction. The regression equation that obtained is $\mathrm{Y}=1,424+0,273 \mathrm{X}_{1}+0,689 \mathrm{X}_{2}$. This number shows that the coefficient of achievement motivation $\left(\mathrm{X}_{2}\right)$ bigger than the principal's supervision coefficient $\left(\mathrm{X}_{1}\right)$. The amount of correlation coefficient that obtained for 0,391 . The calculation result $F_{\text {count }}$ with a critical value of $F$ distribution at significance level $5 \%(\alpha=0,05), \mathrm{dk}=(2,58)$ obtained $F_{\text {table }}$ in the amount of 3,15 . The value indicates $F_{\text {count }}>F_{\text {table }}(5,23>3,15)$. Therefore, it can be concluded that the equation of multiple regression lines is showing significance at a significant level $5 \%(\alpha=0,05)$ So it can be concluded that the hypothesis there is a significant and meaningful relationship between principal supervision and achievement motivation together with teacher work satisfaction is acceptable.

4. Essentially principal's supervision and achievement motivation are only a few factors related to teacher job satisfaction.

\section{REFERENCE}

[1] Robbin, Stephen P. and Mary Coulter. Management, Edisi Ke-8 Alih Bahasa. Harry Slamet dan Ernawati Lestari. Indonesia, Macanan Jaya Cemerlang, 2007, pp. 105.

[2] Gibson, James L, Jhon M. Ivancevich and James H. Donnelly. Organisation, (Djarkasih, Terjemahan) Jakarta: Erlangga, 2006, pp. 67.

[3] Kumar, Jajara and Rao, B.D.," Job Satisfaction Of Teacher, " New Delhi : Sachin Printers, 2007, pp. 95.

[4] Suwar. Persepsi Guru Terhadap Kepemimpinan Kepala Sekolah dengan Motivasi Kerja dan Kepuasan Kerja. [On-Line]. AvailableFTP, 2008, pp. 79. http://guruvalah.20m.com/. Tanggal akses 4 Desember 2012.

[5] Hughes, Victoria M. 2006. Teacher Evaluation Practices and Teacher Job Satisfaction. Makalah dipresentasikan untuk the Faculty of the GraduateSchool University of Missouri-Columbia. [On-Line]. Available FTP:http://edt.missouri.edu/Fall2006/Dissertation/HughesV120806D554 7/research.pdf. Tanggal akses 4 Desember 2012.

[6] Sopiah. Perilaku Organisasi, Yogyakarta: Andi, 2008, pp. 170.

[7] Winardi, J. Motivasi dan Pemotivasian Dalam Manajemen, Jakarta: Grafindo Persada, 2007, pp. 137.

[8] Usman dan Akbar. Pengantar Statistik, Edisi Ke 2. Jakarta: Bumi Aksara, 2008, pp. 293.

[9] Sudjana. Metode Penelitian Statistik, Edisi Ke-6 Bandung: Tarsito, 2005, pp. 66-330

[10] Arikunto, Suharsimi. Prosedur Penelitian Suatu Pendekatan Praktik. Bina Aksara. Jakarta, 2003, pp. 188.

[11] Sunardi, Hubungan Supervisi Kepala Sekolah dan Motivasi Kerja Guru dengan Kepuasan Kerja Guru SMK Negeri Se-Kota Samarinda. Tersedia: http:guruvalah.20m.com. 2010.

[12] Yunus, Studi korelasional antara iklim organisasi dan motivasi berprestasi dengan kepuasan kerja guru SMK negeri se kota Samarinda. Tesis. Jakarta: Program Pascasarjana Kepndidikan Universitas Negeri Jakarta. 2004. 